\title{
Part Two, Book One: Creation, or the Everlasting Ground of Things
}

\author{
Jules Simon
}

Rosenzweig begins Book One of Part Two in a familiar yet strange way. ${ }^{138}$ It is familiar in how he immediately takes up an already established narrative from the Bible through simply repeating the statement that "God spoke". It is strange, however, because the first thing he draws our attention to in the phrase "God spoke" is how it expresses a temporal condition. It occurs in the form of the grammatical past tense whose content refers us to a previously silent and invisible-because interior-act of the will. That act is one of the strangest and most mysterious of all acts, namely, the act of creation. To create something newfor example, something literally out of nothing-entails putting into motion a powerful expression of spontaneous willfulness. As Rosenzweig notes, this spontaneous expression is what constitutes something totally new, that is, that something could be created out of nothing is understandable as the apparently miraculous prophecy of a process that has become a visible actuality. And that process is the process of our experiencing anything at all. Moreover, the very fact of communicating an understanding of our experiencing anything at all and having that be understood by another is a novelty of human community

${ }^{138}$ The content of the following chapter is largely derived from Chapter Two, "Renewing Narrations or Chaos in Creation", of my book Art and Responsibility: A Phenomenology of the Diverging Paths of Rosenzweig and Heidegger, New York 2011, 57-84.

How to cite this book chapter:

Simon, J. 2021. Part Two, Book One: Creation, or the Everlasting Ground of Things. In:

Brasser, M., Bojanić, P. and Ciglia, F. P. (eds.) The Star for Beginners: Introductions to the Magnum Opus of Franz Rosenzweig. Pp. 83-97. London: Ubiquity Press. DOI: https://doi.org/10.5334/bco.h. License: CC-BY 
only able to be enacted through speech because how we talk to each other refers us to our experience of things in the world. To better understand this point, Rosenzweig distinguishes between a creator, in this case, the creator from the biblical story called god, and whatever it is that a creator creates. In order to do that, however, Rosenzweig says that we have to better understand what speaking itself is all about.

As a visible actualization, the process of speaking itself becomes a miraculous beginning. Initially, it is miraculous in the sense that Rosenzweig has already delineated, namely, it is something about which we can wonder and marvel. It is an actually existing something that is not me or simply an element of my psychological makeup. To make his point, and to get to his next point about separating the act of a creator and the creation itself as something other than the creator, Rosenzweig returns us to his earlier metaphysical discussion from Book One, Part One about negation and affirmation in their immediate relation to their origin in the nothing. Here, at the beginning of Part Two of his book, Rosenzweig more strongly emphasizes the non-dialectical character of the relation of these two moments, that is, the moment of speaking as a moment of communication between two humans correlated with the moment of creation as the relationship of creator to creature or created thing. The process is not dialectical but is one of confrontation - of a Begegnung -and thus happens as a meeting of two opposites that creates a transformation. This most significant of all transformations originates as an inner struggle of negation with its achievement of a defining sense of self-freedom, to an outwardly directed expression of positive freedom.

Rosenzweig uses packing and unpacking a trunk in order to emphasize the existential awareness of the empirical changes in our condition in which we are involved when we undertake an intellectual journey.

\section{PACKING}

\section{GOING AWAY}

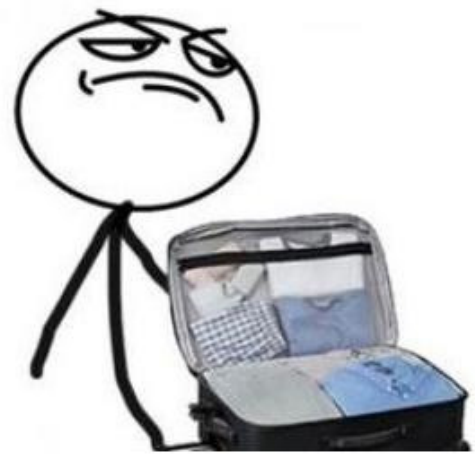

COMING BACK

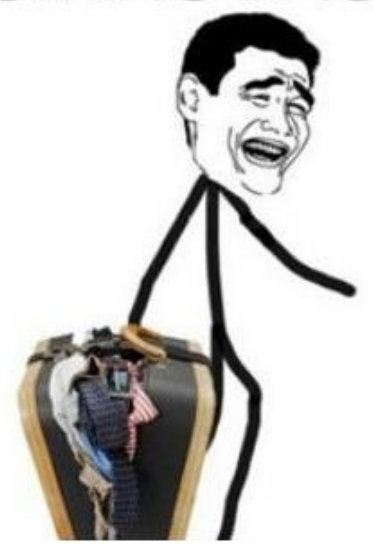


The metaphor of "packing and unpacking" prepares us for his claims about the nature of undergoing any experience whatsoever, namely, that the actual, empirical experience of packing this or that thing in a suitcase changes the order of how we understand, and thereby interpret, things when we unpack them. This means that our understanding is conditioned by the fact that at one time in my life I experienced something one way, like putting clothes into a suitcase, and then at another later time in my life I experience those contents otherwise as I remove them-after having undergone an experience-in a reordered fashion from the suitcase. In other words, I do not experience things as the self-same things over time because temporal and spatial "intuitions" - to borrow some Kantian terms-are filters for our dynamic experiences that do not allow us to reduce those experiences to a timeless account that could be repeated in an endless loop of identical iterations.

The correlation of analyzing the process of speaking with the process of creating enables Rosenzweig to talk about a human phenomenon that occurs when we speak of god's self-expression-visible now through how he conceptualizes 'god's' speech-act, that is, that god created. Such a speech-act is the beginning of god "shining forth" in self-expression. This shining forth is the self-expression of god's structure, god's configuration, and is god's essential attribute. But what, more precisely, does it mean to express oneself as 'shining forth?" Shining forth has to do with the power of self-expression that becomes how more than one of us understands the experience of moving from spontaneous and willful caprice to the peacefulness of enduring essence that Rosenzweig traces in his description of how one, as subject, objectively expresses one's essential nature as creator.

Through talking about the relationship of a creator and speech, Rosenzweig explicates how self-expression is a visible process, not as deed, but as essence. It is visible as essence in the way that phenomenal existence of self-expression can be 'seen' and 'heard' through the very act of speaking that becomes the tangible marker of a prior willful act. To put it simply, the very act of speaking embodies in its expressive 'shining forth' the 'wisdom' that is the experience of having done something, of having created some thing. More concretely, Rosenzweig explicates the expressive act of the shining forth of an experience through a complex analysis of necessary versus freely spontaneous acts. He notes that god 'must' create, "like the artist" in order to satisfy a divine need within himself, namely, in order to set the burden of loneliness within himself free. And while to be free it is necessary to create, Rosenzweig notes that there can not be even one drop of passion in this creative act, neither a yearning to love nor a Maimonidean sort of overflowing love, ${ }^{139}$ because if creation happened out of such a need, then the created thing would lose its own independence. The world, for example, would lose its elemental characteristic of independent createdness, its having been created at one time and its character of being left on its own to develop as it will.

139 Which is not a Maimonidean rational construction, even if depicted via negative theology. 
For this reason, Rosenzweig returns to the notion of caprice, noting that it is not merely a cornerstone but the foundation stone for any theory of creation. But now caprice has to be reinterpreted to fit Rosenzweig's narrative structure, not as a fixed attribute but as dynamic occurrence that "burned with ceaselessly renewed flame in God's bosom before creation" 140 - a "flaming caprice" with which the creator vitalizes himself within himself, and which occurs as miraculous, creative power. This creative power manifests itself in serene vitality but at the base of that power is unconditionally free caprice. That is, that which is within is not necessity, but radically free caprice, not passionate need understood as a completing or clinging kind of love, but simply an expression of inner freedom.

Rosenzweig begins Book One of Part Two by asking us to think about a very specific kind of speech-act, that is, he begins by providing us with a speechact that is a form of speech-thinking that syntactically occurs in the past tense but that semantically refers us to a historical and philosophical narrative about how to think about god as a Creator God, the grammatical subject of the phrase, "God created". This leads us to consider how we understand what it means to create something at all, namely, how to understand and then to speak about what it means to bring something into existence and for that something to exist. The project is a meta-linguistic exercise that leads us to the thought of how that something could be the world (or universe) as an existing entity consisting of a plethora of particulars that must ever be renewed to maintain their enduring, transitory existence.

To be distinctive, ${ }^{141}$ is to be counted as a chaotic particular, willfully involved in a process of creative self-transformation that negates all others. This is what Rosenzweig means when referring to the particulars birthed out of the world itself, represented by the essential nature of this or that 'universal' species. But the particular also retains traces of its origination out of the universal essence and thus retains the character of that essence itself. Thus endowed, it is not merely logically deduced from its source; rather, it is endowed with existence and can be counted as an existing particular individual.

This picture of a plastic, dynamic world, in Rosenzweig's account, is "universal" but is not "always and everywhere" because it is constituted as particularity and so must continually become new in order to continually 'contain' this concrete particularity called existence. But in order to continue to contain its concrete existence, its character of absolute empiricism, the world must continually undergo a necessary process of transformation-birthing absolutely free and arbitrarily willful, ever-new particulars, or existents, that crystallize

140 SE 128; The German words in this context are: caprice-Willkür; cornerstone-Eckstein; foundation-stone-Grundstein; attribute-Eigenschaft; occurrence-Vorgang or Ereignis.

141 The German expression is: eine Besondere which has the connotation of something that is singular and separated out of a larger whole. 
as they grow older to form a completion in death as a denial of life, fixed with the character of thingliness. Upon completion of this specific form - the form of an ephemeral denial of enduring life - new particulars emerge, constantly denying the stability of the world and yet ever-becoming that stability again, and so on. This is also a way to understand the dynamism of the entire structure of Rosenzweig's book with its symbolic configuration as a Star of David.

Rosenzweig adopts an old term, providence, and coins a new one, "creature consciousness", in order to suggest the logical and aesthetic differences between his account of the world process and Idealist accounts. ${ }^{142}$ On providence, he says that the "divine grasp of existence does not occur in creation, which took place once and for all. Rather, it is a momentary grasp, a providence that, though universal, renews itself with every smallest distinctive moment for the whole of existence in such a way that God 'day by day' renews the work of the beginning"143. And it is this very consciousness of their creatureliness that radically differentiates humans from other life forms because that consciousness gives us a capacity for aesthetic presentation. Humans speak in different ways with each other that includes creating works of art that "speak" from the particularity of one human to their commonality with other humans. That distinction is accentuated in differentiating between the "dead" languageform of mathematics and the "living" grammatical distinctions of spoken language referred to in the transition from Part One to Part Two.

Obviously, we have kinds of laws that take the form of rules of logic, namely, premises, deductions, inferences, and conclusions that can be modeled mathematically. But there are also kinds of laws of grammar that result from investigating the emergence of hearable root-words from what Rosenzweig introduced earlier as the silent source-words. The source-words are "Yes, No, And" and they function as variables in a differential calculus that corresponds to his model of the hypothetical structures of the pre-world. Those hypothetical structures enable us to think about any one of the three primary elements of reality according to their respective 'logics': god world human. What makes Rosenzweig's philosophy distinctive and still compelling is how he correlates the 'logic' or laws of grammar with a midrash on the story of creation, claiming that, through the familiarity of a re-narrated and newly interpreted traditional narrative, we can better understand how words work and how and why they occupy the space that they do in the sentences composed of them. That is, we can better understand why we choose and use the words that we do in creating or not creating understandings in our inter-subjective relations. Said otherwise, the grammar of words and sentences can be related to the emergence of particulars in creation as a way of accounting for the renewal of the unconquerable and anarchic dimension of the chaotic, spontaneous freedom at the root of

${ }^{142}$ Both Hegelian and all others: Kantian, Fichtean, Schellingian, but also Platonic/Aristotelian and Maimonidean.

${ }^{143}$ GS II, 135. 
human distinctiveness. Words are related to creation because what we say about creation-about the world-also has to do with things and the space that they occupy. The sensual nature of words, both written and spoken, makes them the special case of being both thing-like-having to do with world-space-and temporal and ephemeral, that is, speech includes an essentially chaotic dimension that is open to change over time. And in order to catch the sense that chaos plays in our speech-acts, we must begin with sentences, not words.

To make his case, Rosenzweig employs a speech-thinking (Sprachdenken) analysis of the syntax and semantics of the adjective ${ }^{144}$ as the grammatical analogy for the particular nothings of creation. He moves our attention from the relationship of an adjective, with its initial indefinite case, to the noun as the carrier of adjectives, to the pronoun "this". The underlying logic is deductive, namely, to understand anything in particular we must first be given and then understand something in general. Such is the sentence. Such is also the world. The indefinite and inherently comparative nature of the adjective "this" points us towards the fact that a "something" should be sought as a concrete, definite referent. Moreover, along with the "this" is implied a spatial indicator, the "here", which entails that space is posited as the universal condition under which the definite thing, so far only an undefined "something", is to be sought. Given the initial evaluative affirmation of the adjectival attribute we are led by logical inference to consider the noun and then the pronoun, which consequently points us to space as the dimension of objectivity and the general nominative 'space' called "thinghood" where we find actual things in the world. ${ }^{145}$ Guided by grammatical structures in the use of our everyday language, we are determined to seek out things in the general context of their thinghood as that which constitutes the space of the world in which we live, psycho-physiologically.

For example, in getting us from using an indefinite adjective to a more definite sense of substantiality - of the general, predicate 'space' thinghood-is important because of the apparent problem that in any speech-act an individual adjective is merely one of many that could be used, indicating that there is an unacknowledged plurality always at work in our speech-acts. This is what Rosenzweig earlier referred to as the complex ordering problem of the "perhaps". In the context of the set of language practices as a whole, however, we have more than just sentences composed of variables. Indeed, adjectives can also become definite by being affixed to a definite article. Rosenzweig notes: "fixed by the definite article, the adjective is a definite, affirmed thing in the endless space of cognition or creation." 146 What makes Rosenzweig's account special is that he correlates this syntactical arrangement as a semantic analogue to his creation thinking, such that when we realize how the adjective "comes to rest" as a grammatical object in the sentence and stands "free and affirmed"

\footnotetext{
${ }^{144}$ Attribute word, or adjective: "Eigenschaftswort".

${ }^{145}$ Cf. GS II, 142; SR, 127.

${ }^{146}$ Ibid., 143; 129.
} 
we can, by analogy, think about how the created stuff of creation stands in an objective relationship "free and affirmed" to the creator. ${ }^{147}$

But to truly understand how the world is a created thing, Rosenzweig tells us that we have to understand how it is "totally, in its primal origin, the fullness of the this", which is expressed by means of adjectival words. For Rosenzweig, another way of describing this fullness is to call it chaos, what he calls the "firstling" of creation. In fact, the world is not created until this existence, this chaos, is itself first called into existence. And existence, in its universality and all-embracing formfulness, remains the immediate, created ground, the "beginning", out of which the ever-new births of the fullness shoots forth. ${ }^{148}$ No chaos, no creation, no world. The fullness, as chaos, is its transitory appearance as particular existents, which is also the first utterance we can make about the world's existence.

There is an ethical significance for Rosenzweig's grammatical analogy in how the very existence of the world corresponds to the rootword of creation, the "primal yes" or the "Yes!" that he interprets as an affirmative and evaluative "Good!" uttered in judgment upon completion of an act of creation. It is an estimating judgment that logically occurs before the fullness, before the chaos of adjective-words. And thus, according to Rosenzweig's linguistic account for creation, "chaos is in creation not before it; the beginning is-in the beginning", which is the act of creation. ${ }^{149}$

Rosenzweig is critical of Idealist kinds of aesthetics because of how those philosophies contend that we should only think about the world in which we live in terms of a deductive logic that presupposes both a rationally defined source and a rationally defined goal. That kind of thinking is problematically based on a principle of generation whereby a succession of particulars identical to the original generator is produced and that has a built-in teleological goal of an ordered cosmos. ${ }^{150}$ Rosenzweig's concept of creation, by contrast, reveals an ordered cosmos, but does not entail either a rational connection between

${ }^{147}$ Ibid. The German word Rosenzweig uses to characterize this condition is "Gegenstand", which literally means that-which-stands-over-against an implied or specified other. Rosenzweig constructs a mental bridge from the actuality of the grammatical distinctions to those of relations which hold in thinking about creation: It (the object) now "stands" there on its own feet over-"against" a supposed creator, a definite, affirmed thing in the infinite space of cognition or of creation. This is his metaphysics of the elemental thought-constructs involved in any process of creation or creative act.

${ }^{148}$ Ibid., 148; 134.

149 Ibid.

${ }^{150}$ In Schelling's case, the generating principle is the ongoing production of the identifying of non-identical principles, for example, the Real and the Ideal, in what he calls a doubling (Doublirung) of the initial unity, whose ultimate goal is the exclusion of non-being as evil. However, the final redemption 
the world and its creator or the presupposition of an ultimately ordered cosmos except for the fact of the act of creation itself. Rosenzweig tells us that creation includes, by definition, an anarchic dimension since, as an event that is freely produced, it is not set in a previously ordered horizon determined by this or that principle. ${ }^{151}$ For Idealist philosophers, "Generation should accomplish the same as creation; it should give to the plastic, objective world, the world as Antiquity saw it, the point from which its multiplicity closes together and orders itself in unity"152. By positing the concept of a creator whose only relation to the world is that of having created it, we are able to think of a created world as being separate and thus having pictureability and plastic selfcontainedness, aesthetic traits already also elaborated in Antiquity ${ }^{153}$ Given a concept of a god that is not so inextricably bound up in managing the laws of the world allows us to represent to ourselves a picture of a world that is not chained to a causal determinism that would undermine the basic insights of standard empirical philosophy or the possibility of radical, ethical freedom. ${ }^{154}$ In Rosenzweig's model, we are given the conditions that enable us to imagine a sense of ourselves in a world in which we are able freely to act and to create new things and new relationships.

In order to differentiate the phenomenon of speech-thinking from the generative logic of Idealist thinking, Rosenzweig uses garden imagery to suggest

that Schelling has in mind is ultimately very Christian: God becoming man and then everything, i.e. nature, becoming God the Father.

${ }^{151}$ Whereas in the Idealist tradition, precisely in order to circumvent the concept of creation and to provide an ordering connection, all Idealist philosophers resort in one way or another to a concept of generation that leaves no gaps in its logical development.

${ }_{152}$ GS II, 149; SR, 135.

${ }^{153}$ Rosenzweig literally means "pictureability" when he uses "Bildhaftigkeit".

${ }^{154}$ See Rosenzweig's thoughts on empiricism in Das neue Denken in GS III. See also Robert Gibbs, Correlations in Rosenzweig and Levinas, Princeton 1992, 128, for his argument that Rosenzweig's theological sociology presents a theory of redemption as social action that "is an empiricism of the future - that we can make society conform to these concepts, and so redeem the world". See also Norbert Samuleson, A User's Guide to Franz Rosenzweig's Star of Redemption, Surrey 1999, 60, for his judgment that Rosenzweig would restrict all variants of philosophy, including empiricism as a modern form of Atomism, to his general critique of traditional philosophy at its philosophical best, i.e. as idealist philosophy. However, in his logic of creation, Rosenzweig maintains a firm link to the empiricist tradition by citing Bacon in order to express the empiricist principle that the future is absolutely unlike the present and cannot give us knowledge of what is actual or of actuality: "Gar die Zukunft gilt als absolut ungeeignet 'unfruchtbar' für die Erkenntnis des Wirklichen.” (GS2, 146; SR, 132). 
how language is rooted in the primal word, which is a counter-argument on his part for an alternative sort of logic, yet is only able to grow and flourish through practical actualization in human relations. ${ }^{155}$ It grows and renews itself because language is a kind of living and growing "art" form in the way that language and life mutually nourish each other. In order for language to happen at all, there must be a lived world where humans share their experiences with each other. It is precisely this point that distinguishes Rosenzweig's philosophy of language from an Idealist or analytic philosophy of language. Where an Idealist or analytic philosophy of language contends that all forms of human speech can be reduced to symbolic designators and algebraic formulas, Rosenzweig contends that doing so robs language of its rootedness in human sensuality and its ability to transform humans-through its trans-sensuality-from tragically isolated selves to existing, colorful, soundful souls able to touch and move each other. That happens as the process of revelation, the theme for the next chapter.

Proleptically, however, the work of creation-thinking shows that, because Idealist thinking lost contact with the living vitality of unpredictable existence and was "sunk-down in the under- and pre-world shadow realm of logic, it ... [had to seek and]... to hold open an access to the over-world"156. It sought this access because it had lost trust in language since it was not the work of its own hands. ${ }^{157}$ Acting from the spur of a guilty conscience, Idealists needed another supposition to mediate and thereby confirm the dynamics of reality, a substitution that had to be a human garden in which humans themselves plant the structures of mediation but which retains the character of unconsciously arising as if without human involvement. That was art. ${ }^{158}$ Art became the vehicle for Idealist philosophers to visibly and empirically justify their need

155 Although language is rooted in the primal-words in the subterranean grounds of being, it already shoots upward into the light of terrestrial life in the root-words, and in this light blooms forth in colored multiplicity. It is, therefore, a growth in the midst of all growing life, from which it is nourished as that life nourishes from it! Language is differentiated from all this life because it does not move itself freely and arbitrarily above the surface, but rather stretches down roots in the dark grounds below life.

156 GS II, 162; SR, 146.

157 Cf. for this the Introduction to Part Three where Rosenzweig refers to Goethe's drama Faust for how the ideal human condition is to exercise total independence in the course of one's life. Rosenzweig goes on to reconstruct for us a plausible scenario for what happened next in the historical record of the development of Idealism.

158 See Immanuel Kant, Critique of Judgment, J. H. Bernard (trans.), New York 1951, 78. For Rosenzweig, the Idealists apotheosized art by making art into a god-like phenomenon and removing, thereby, its particularity as its embededness in human distinctiveness. Moreover, art became a garden with the kinds of signs that the art-work is directed to a purpose and yet at 
for methodological completeness in their panlogistic ordering of reality. ${ }^{159}$ The artwork provides the "visible" proof of an "absolute" verification of certainty that one's roots are drinking from "the" reality of the All and therefore quells the doubts that dwell at the root of all philosophical undertakings.

Hence, instead of believing in the "speech of the soul, which is a self-revelation of human innerness that encompasses, supports, and completes all other self-expression", an Idealist trusts merely in art in itself, in one torn-off limb of humanity. ${ }^{160}$ But for Rosenzweig, what it means to become fully human is precisely to become "ensouled", which means accepting that a human life is not, in essence, a work of art, even though without that limb humans would be crippled. Without art a human would still remain human but without the spoken word of language, which testifies to a human's soul, a human ceases being fully human.

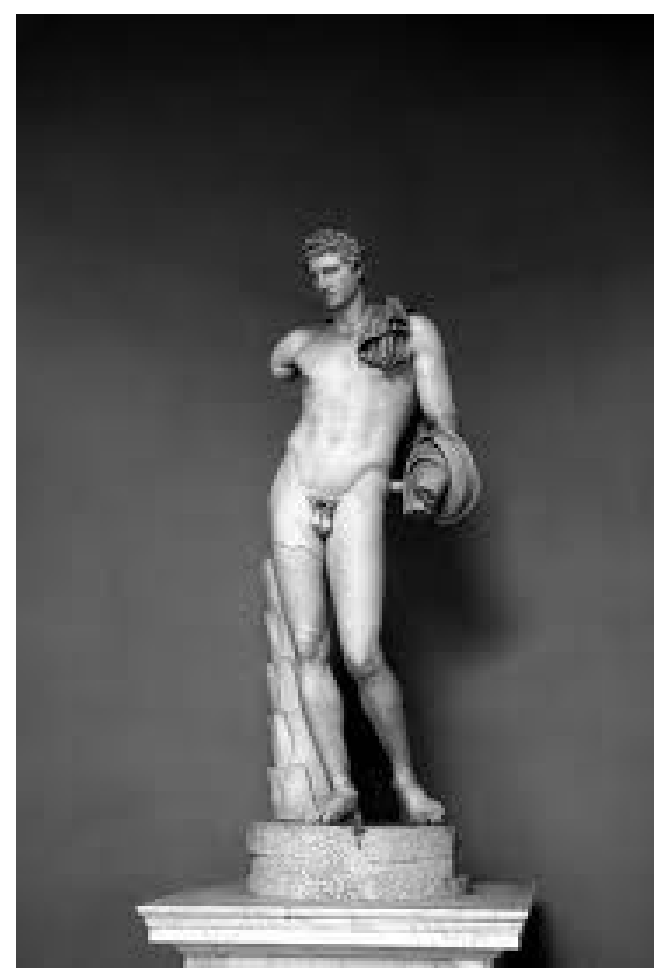

the same time comes about without purpose, quite like the Kantian idea of a purposeless purpose set out in his Critique of Judgment.

159 Rosenzweig says: "When doubt overcomes him about the admissability of its method of the 'panlogistic' pure generator, he only needs to look at the art-work, produced by spirit and yet also part of natural reality, in order to again obtain a good conscience."

${ }^{160}$ GS II, 163; SR, 147. 
Just as creation can be said to be only the beginning in the framework of world-time, so the creation of an artwork is only the beginning of the work of humans in the world and the beginning of the effects of the work itself through time. Involved in understanding the formative process of a work is also the effect of the work on the viewer. Returning again to speech, Rosenzweig tells us that the present effect is also the revelatory effect and that has to do with language. ${ }^{161}$ Indeed, Rosenzweig distinguishes between "spoken language" as such and "the living, streaming actuality of actual speech"162 in order to highlight the difference between grasping the intention and expression of a speech act (or act of creation) and the actual effects of its becoming or its completion in the other, in the viewer. We only "see" the beginning - in creation-but not the ongoing or completed life of the work. That entails revelation. Only in the revelatory "saying" of actual, living, streaming language is "human content" able to be expressed by way of the beautiful "artwork". What is "exposed" or freely brought out in the "life-day of the work of art", in building up a work of art, are individuals. These individuals take the form of a kingdom of details-the adjectives - that emerge from a pre-aesthetic totality in an historical procession from the "ground-concepts" to an aesthetically rich actuality. Rosenzweig identified for us three foundational examples of such productions in Part One: god-as-mythic, world-as-plastic, and human-as-tragic. ${ }^{163}$

Towards the end of this chapter, the sections on genius, poet and artist in The Star connect Rosenzweig's theoretical discourse in Part One with his practical demonstrations in Part Two, especially with how he interprets biblical texts as exemplifying how creative acts are tied up with language and established narratives. Rosenzweig first tells us that the creation of the artwork happens in the author, using the word "Urheber" for author. ${ }^{164}$ Rosenzweig wants us to think of the activity of the genius-as-author in terms of one who draws something up or out of an already existing reservoir, out of the primal depths and wealth of one's own pre-existing reservoir, that is, from out of one's own autonomously developed substance. ${ }^{165}$ Hence, creation of the artwork happens not so much as an act of remembrance that breaks out of the author, as with Plato and other Idealists, but is an activity of becoming that presupposes the status of the author already having become someone who is capable of bringing forth a new and original work. Rosenzweig names this state: being-already-created.

${ }^{161}$ Ibid. This is his fusion of aeshetics and theology.

162 Ibid.: "gesprochene Sprache” and „der lebendig strömenden Wirklichkeit der wirklichen Sprache".

163 GS II, 165; SR, 148.

164 Ibid.

165 Since one of the etymological roots of Urheber means to raise out of the primal depths. The work of art is raised out of the primal, pre-reflective and pre-linguistic depths of a particular author revealing the created work as a process of bringing something forth that is already there. 
He points out that the happening of the work of art in its relation to the viewer depends on the viewer for its completion, a completion that is measured by its degree of actual liveliness. This provides an important part in Rosenzweig's theory for the role of art as cultural and political phenomenon. As one of the criteria for measuring the actual effectiveness of a work of art, the liveliness is that aspect of the work that is capable of arousing a feeling of common humanity in others, that is, liveliness presupposes that there is another human other than myself who, through that work, awakens me as I awaken her by way of experiencing a lively feeling of our common sense of humanity. That awoken feeling then initiates a process within the other which leads to the formation of self-identities through instigating a process of self-reflexivity initially based on the formation of a perceived sense of commonality. That commonality is that the other is like me but shares a human commonality that is, however, in the next instance negated in order to allow for one's own self-affirmation.

In order to better elucidate his ideas about this matter of self-identity, Rosenzweig turns to an ideal case, namely, the case of the genius and the "eruptive" act by which someone becomes marked as a genius by an evaluating public. The issue of the "genius" is not new with Rosenzweig, but instead indicates his roots in the German Idealist preoccupation with using such a term to categorize extraordinary works of human production. ${ }^{166}$ Rosenzweig rejects the assumption that only an elite, pre-determined few in a process of natural selection have been predetermined, that is, pre-selected, to become geniuses. He argues that if geniuses were born to inevitably become geniuses then the category of personality would provide the criteria to determine who is or is not a genius, whereas personality is simply that determination of a human being that results from cultural and environmental factors and not genetic heritage. Instead, the category of genius is tied to the category of self and to become a self is open to almost everyone, as Rosenzweig notes: "Miracle-children have just as much, or just as little, chance to become a genius as any other human."167 Just as a self "suddenly surprises someone one day", so genius "surprises someone one day". What is common between the genius and every other self is that both presuppose a pre-existing totality of human being whereas what differentiates the genius from every other self is that the genius, drawing on his/her "complex of in-genius characteristics", which constitute its ownmost self, is able to draw from within him-/her-self and set free a work. ${ }^{168}$ It now becomes apparent how important the earlier presentation and analyses of freedom, caprice, and necessity is for Rosenzweig's position. ${ }^{169}$ Being able to draw from within oneself and

${ }^{166}$ See Immanuel Kant, Critique of Judgment, J. H. Bernard (trans.), New York $1951,150-64$.

167 GS II, 165; SR, 148. (My italics.)

168 Ibid.,166; 149.

169 See Chapter Two in this text, where Rosenzweig establishes the metaphysics for his Cohenian-inspired, mathematically based epistemology. 
to set free a work is what constitutes the difference between genius and nongenius and not personality as such. ${ }^{170}$

Rosenzweig expands that definition of genius/author to include every human being capable of becoming a self but restricts members of that set to those who are capable of "increasing and completing oneself within oneself" 171 . What this means is that the genius is able to "begin a new beginning" because the emergence of genius, with respect to personality and self, is the beginning of a new phase of one's life. But the true genius has to become a poet, as opposed to being just an artist-since every genius is an artist but not every artist is a genius. ${ }^{172}$ This means that the genius has to have access to an "inner manifoldness, a world of creations, of imaginative insights and thoughts which . . . harmoniously strive towards each other in simply being with one another"173. Rosenzweig calls this harmonious inner striving of co-existing thoughts "family resemblances", a concept that connects his ideas about art with the ethical relationship of dialogue, developed later in Part Two and instrumental in his social theory of responsibility that he develops in Part Three. He also notes that unless one is capable of inexhaustibly producing new creations out of this "covenant" of family relations, then one is a "crippled" genius. It seems that the life of the genius, although open to everyone, is actually very demanding and complex.

Finally, Rosenzweig ends the chapter with his midrashic interpretation of the opening passages of Bereshit (Genesis). In exercising his midrash, it becomes clear that he does not negate or reject art or mathematics, which would then be submitting to the inexorable appropriation of a dialectical logic; rather, he

170 The distinct divergence from attributing genius to personality may also indicate Rosenzweig contesting, again, Hegel's phenomenology of social ethics articulated in The Philosophy of Right. In sections on "Abstract Right" Hegel claims that self-determination in any society has its origins in the stipulation of personality as "the' defining human characteristic, which then leads to his theory of property rights, etc. See G.W.F. Hegel, Grundlinien der Philosophie des Rechts, Stuttgart 1970, 115-23.

${ }^{171}$ GS II, 166; SR, 149.

172 Which sets him against Hegel as well. Rosenzweig provides us with a pair of examples to differentiate between poet and artist: Flaubert as mere artist versus Balzac as poet, and Huch as artist versus Lagerlöf as poet. The difference is that in the case of Flaubert and Huch, their artistry consists in their attempts to retell history realistically in some kind of mirroring effect. Balzac and Lagerlöf, on the other hand, create new adventures and comedies to depict society as such but also possible social relations. Additionally, Rosenzweig provides gendered pairs, Balzac and Flaubert are both male, Lagerlöf (who was the first woman to ever be awarded the Nobel Prize for Literature in 1909) and Huch are both female.

173 GSII, 166; SR 149. 
proceeds phenomenologically by taking art and mathematics as presuppositions and proceeds by building their transformation from static placeholders in a metaphysical sort of logical atomism-whose power is the analysis of the individual point-into the building stones for a story which descriptively reveals that which is believed to be a dynamic, self-renewing course of actual emerging creations and relations. The hypothetical and isolated elements are withdrawn from within the author and assembled to form a philosophical/ theological/sociological narrative that makes ethical and thus corresponding sense of the different elements in the narrative. It is also ethical because ethical relations depend on establishing relations of believing trust in the language that comes naturally to us. In Rosenzweig's words: "We describe the course in which we believe, with the words in which we trust."174 But which words should we trust? Which do we believe in and where do such words come from? What do we mean when we talk about trust?

We trust because we are accustomed to using something based on our faith in its reliability. Rosenzweig tells us that it is necessary to trust language, which is easy because of its utter familiarity. ${ }^{175}$ We trust in that language that resounds for us with a sense for familiar, joyful, and fruitful relations and that bridges our inner radically subjective experience with our objective experiences of others in, with, and of the world. ${ }^{176}$ Simply put, what we hear from the other is what we intuitively say from our own hearts. That means that even though the innerstructural processes for constructing the elements "god world human" can be and should continue to be differentiated, Rosenzweig asserts that the "word of god and the word of the human are the same" in how they resound with actuality for us. ${ }^{177}$ At this end-point, as at the beginning of Book One, what Rosenzweig means by god is simply a speech-act referring to that one who at one time created something out of nothing, an act about which we continue to speak.

\section{Further readings}

Bauer, A.E, (1992). Rosenzweigs Sprachdenken im "Stern der Erlösung" und in seiner Korrespondenz mit Martin Buber zur Verdeutschung der Schrift, Frankfurt a.M., Lang

${ }^{174}$ GS II, 167; SR, 150.

${ }^{175}$ Language is in us and around us, and there is nothing else which comes to us from "without" (aussen) in the way that it resounds (widertönt) out of our "inner" (Innen) to the "outer" (Aussen). The word is the same as it becomes heard and as it is spoken GS II, 167; SR, 150.

${ }^{176}$ Interiority and exteriority, as such.

177 Accordingly, drawing on what is closest to his own heart, Rosenzweig claims that what human beings hear in their heart and take to be their own human language is "the word which comes out of the mouth of god". But what exactly Rosenzweig means by god is not at all clear. 
Del Prete, M., (2009). Erlösung als Werk. Zur offenbarten Ontologie Franz Rosenzweigs, Freiburg, Alber.

Kalatzis, A., (2021), Episodic Genius. Autonomous Artistic Agency in the Star of Redemption, in: "Into Life", Franz Rosenzweig on Knowledge, Aesthetics, and Politics. Supplements to the Journal of Jewish Thought and Philosophy 31 (2021) 111-138; [https://doi.org./10.1163/9789004468559_007]

Schwartz, M., (2003). Metapher und Offenbarung. Zur Sprache in Franz Rosenzweigs «Stern der Erlösung», Berlin, Philo. 